\title{
FAHAM ULAMA HADITS DAN SUFI TERHADAP KEYAKINAN TENTANG NUR MUHAMMAD
}

\author{
Achmad, M. Muhtarom Ilyas
}

\begin{abstract}
Abstrak
Nur Muhammad adalah suatu ajaran tentang keyakinan bahwa Allah SWT menciptakan Nabi Muhammad SWA dari NurNya [Allah SWT]. Sejak semula dari Nur Allah itu dicipta Nur Muhammad, hal ini telah menjadi aqidah para penganut thariqat atau mereka yang bertasawuf dalam Islam. Bila Nabi Muhammad SWA diciptakan berasal dari NurNya, demikian halnya seluruh makhluk juga diciptakan dari Nur Muhammad. Dari NurNya, Allah SWT menciptakan Nur Muhammad dan dari Nur Muhammad, Allah SWT menciptakan seluruh makhluq. Keyakinan tentang Nur Muhammad mempunyai konsekwensi terhadap wujud yang satu, yaitu wihdatul wujud, kesatuan wujud Khaliq dan makhluq, kesatuan wujud Allah SWT dengan alam semesta. Sebagaimana Al Bushthami mengatakan," Aku heran kepada orang yang mengenal Allah, bagaimana mungkin dia menyembahNya?" Juga Al Bushthami mengatakan,"Mahasuci aku, mahasuci aku, alangkah agungnya aku." Jadi siapa yang telah mengenal Allah swt., dia merupakan emanasi dari Allah swt. sehingga melekat padanya sifat-sifat ketuhanan yaitu rububiyah dan uluhiyah. Oleh karenanya mana mungkin Allah menyembah Allah? Itulah wihdatul wujud sebagai salah satu konskwensi dari ajaran tentang Nur Muhammad.
\end{abstract}

Kata kunci : Nur Allah, Nur Muhammad, wihdatul wujud, emanasi

Bila mencermati sirah Nabawiyah, catatan lengkap perihidup Rasulullah saw. tidak ada satu katapun yang dapat dijadikan indikator sebagai embrio konsep Nur Muhammad. Demikian halnya pada masa khulafaur rasyidin secara samarpun tidak tertedeksi ajaran yang semacam itu, setelah timbul ajaran tasawuf di dalam Islam disela-sela itulah sejarah membuktikan timbulnya embrio ajaran tentang Nur Muhammad, yaitu sekitar abad ke III Hijriyah. Dari sisi lain timbulnya filsafat Islam, diantaranya ada yang membahas tentang teori emanasi atau teori pancaran, pengaruh dari berpikirnya filosof Yunani kuno itu tidak dapat dihindari, masuk di dalam pembicaraan tasawuf Islam, sehingga dapat disebut filsafat yang tidak lagi Islami. Tasawuf sebagai ilmu berkembang sedemikian pesat dengan munculnya berbagai thariqat sebagai jalan menuju kehidupan sufi. Dari sinilah timbul penyimpangan dalam ajaran tasawuf, sebagaimana timbulnya ajaran hulul, ittihad, dan wihdatul wujud. 
Pencetus kesesatan dalam tasawuf yang paling terkenal adalah Al Hallaj, tokoh yang mengajarkan tentang wihdatul wujud, kesatuan wujud antara khaliq dan makhluq. Sedang secara teks Al Qur-an dan As Sunnah, khaliq ya khaliq dan makhluq ya makhluq, bukan khlaliq itu makhluq dan atau makhluq itu ya khaliq, khaliq itu pencipta dan makhluq apa saja yang dicipta, sehingga khaliq berbeda dengan makhluq, laisa kamitslihi syai'un. Penyelewengan Al Hallaj, ulama saat itu memutuskan dihukum mati Al Hallaj. Ini sama dengan Syeh Siti Jenar, seorang wali di tanah Jawa yang juga mengajarkan tentang manunggaling kawula kalawan gusti, wihdatul wujud. Sama halnya dengan Al Hallaj, Syeh Siti Jenar juga dihukum mati oleh para wali di tanah Jawa ini.

Wihdatul wujud inilah wujud nyata ajaran yang dilahirkan oleh ajaran Nur Muhammad, jadi ada relevansi dan korelasi antara wihdatul wujud yang sesat itu dengan ajaran Nur Muhammad.

\section{Landasan Dalil}

Utamanya dalil sebagai landasan hukum dalam Islam adalah Al Qur-an dan As Sunnah atau sering juga disebut Al Hadits, dan ini sudah menjadi ketentuan final, sebagaimana disabdakan oleh Rasulullah saw. ,"Aku tinggalkan kepadamu dua perkara yang jika kamu berpegang teguh kepada keduanya maka tidak akan sesat selama-lamanya, yaitu Al Qur-an dan As Sunnah.” Di dalam Al Qur-an tidak ada ayat yang menunjukkan tentang konsep Nur Muhammad, demikian halnya di dalam kitab-kitab tafsir terdahulu maupun yang modern juga tidak dijumpai bahasan tentang Nur Muhammad. Sedang di dalam Hadits ada riwayat yang menyebutkan, terjemahnya berikut ini.

Rasulullah saw. bersabda,'Wahai Jabir! Sesungguhnya Allah menciptakan sebelum segala sesuatu cahaya Nabimu dari cahayaNya. Kemudian cahaya itu mulai berkeliling dengan kekuasaan ke mana saja yang dikehendaki Allah Ta'ala. Pada waktu itu belum ada Lauh, pena, surga, neraka, malaikat, langit, bumi, matahari, bulan, jin, dan manusia. Setelah itu, ketika Allah hendak menciptakan makhluk ciptaanNya, Dia membagi cahaya itu menjadi empat bagian. Lalu Dia menciptakan dari bagian pertama pena, bagian ke dua Lauh, dari bagian ke tiga Arsy 
(singgasanaNya). Kemudian Dia membagi bagian yang ke empat menjadi empat lalu menciptakan dari bagian pertama para Malaikat pembawa Arsy, dari bagian ke dua Kursi, dan dari bagian ke tiga para Malaikat (selain pembawa Arsy). Sesudah itu Dia membagi bagian yang ke empat menjadi empat. Kemudian Dia menciptakan langit dari bagian pertama, bumi dari bagian ke dua, surga dan neraka dari bagian ke tiga. Selanjutnya Dia membagi bagian ke empat menjadi empat. Kemudian Dia menciptakan dari bagian pertama cahaya mata orang-orang yang beriman, dari bagian ke dua cahaya dari hati-hati mereka, yaitu makrifatullah, dan dari bagian ke tiga cahaya kesenangan mereka, yaitu kalimah tauhid laa ilaaha illa llaah Muhammadur rasulullah. Setelah itu, Dia melihat kepadanya maka cahaya itupun mengalirkan air lalu terteteslah dari cahaya itu 124.000 tetesan air. Kemudian, Allah menciptakan dari setiap tetes ruh setiap Nabi/Rasul lalu ruh-ruh para Nabi itu bernafas, maka Allah menciptakan dari nafas-nafas mereka ruh-ruh para wali, orangorang yang berbahagia, para syuhada', dan orang-orang yang taat dari kalangan orang-orang yang beriman sampai hari kiamat. Maka Arsy dan kursi dari cahayaku, al karubiyyun dari cahayaku, para rohaniwan dari cahayaku, surga dan seisinya berupa kenikmatan dari cahayaku, matahari dan bintang-bintang dari cahayaku, akal, ilmu, dan taufiq (petunjuk) dari cahayaku, ruh para Nabi dan Rasul dari cahayaku, serta orang-orang yang bahagia dan shalih dari hasil cahayaku. Sesudah itu Allah menciptakan Adam dari tanah dan dirakitlah pada cahaya itu, yaitu bagian ke empat. Kemudiaan cahaya itu pindah dari Adam ke Syits dan terus berpindah dari yang suci kepada yang baik sehingga sampai ke lubang sulbi Abdullah dan darinya ke wajah ibuku Aminah. Setelah itu Dia mengeluarkan aku ke dunia lalu menjadikanku penghulu para Rasul dan penutup para Rasul dan penutup para Nabi serta pemimpin orang-orang yang shalih. Begitulah Dia mengawali ciptaan Nabimu, wahai Jabir."

Ada cerita yang menerangkan Nur Muhammad yang berasal dari Nur Allah, yang dari Nur Muhammad itulah diciptakan seluruh makhluk atau Nur Muhammad itu berpindah ke Nabi Adam, ke Nabi Sis, Nabi Musa, Qinan, Muhlaid, Baried, Nabi Idris, Matu, Salih, Malkan, Nabi Nuh, Fanhasyi (Arba'syi), Syalang, Abar, Falang, Raghu, Syarah, Takhur, Azar, dari Azar pindah ke Nabi Ibrahim, Nabi 
Ismail dan Nabi Ishhak. Nabi Ishak berputera dua yaitu Isa dan Ya'kub. Anak cucu Nabi Ya'kub disebut Bani Israil yang sebagian besar menjadi Nabi, seperti Nabi Yusuf, Nabi Syueb, Nabi Musa, Nabi Harun, Nabi Yusya, Nabi Sulaiman, Nabi Uzer, Nabi Zakaria, Nabi Yahya, dan Nabi Isa. Diterangkan lebih lanjut setelah Nur Muhammad ke Nabi Ibrahim, sebagaimana di atas telah disebut berpindah ke Nabi Ismail, Khaidar, Hamid, Jamal, Hambyah, Adnan, Maad, Nadar, Mudar, Ilyas, Mudrikah, Kananah, Nadir, Malik, Ghalib, Lusyi, Kaab, Murrah,, Kilab, Kusay, Abdul Manaf, dan akhirnya ke Bani Hasyim yaitu Abdul Muthalib, dari Abdul Muthalib pindah ke Abdullah. Abdullah menikah dengan Aminah, ketika Aminah hamil, Nur Muhammad pindah dari Abdullah ke isterinya, Aminah.

Maulana Syekh Hisham Muhammad dan Syekh Dr.G.F.Haddad mengatakan tentang landasan atau dalil Nur Muhammad, yaitu surah Al Maidah ayat 15, surah An Nur ayat 35, surah Al Ahzab ayat 45-46, yang terjemahnya sebagai berikut :

Sungguh telah datang kepadamu cahaya (Nabi Muhmmad) dari Allah, dan kitab (al Qur-an) yang menjelaskan.

Allah (pemberi) cahaya (kepada) langit dan bumi. Perumpamaan cahayaNya seperti sebuah lubang yang tidak tembus yang di dalamnya ada pelita besar. Pelita itu di dalam tabung kaca (dan) tabung kaca itu bagaikan bintang yang berkilauan, yang dinyalakan dari pohon yang diberkahi, yaitu pohon zaitun yang tumbuh tidak di timur dan tidak pula di barat yang minyaknya saja hampir-hampir menerangi, walaupun tidak disentuh api. Cahaya di atas cahaya (berlapis-lapis), Allah memberi petunjuk kepada cahayaNya bagi orang yang Dia kehendaki, dan Allah membuat perumpamaan-perumpamaan bagi manusia. Dan Allah Maha Mengetahui segala sesuatu. Wahai Nabi! Sesungguhnya Kami mengutusmu untuk menjadi saksi, pembawa kabar gembira dan pemberi peringatan. Dan untuk menjadi penyeru kepada agama Allah dengan izinNya dan sebagai cahaya yang menerangi.

\section{Analisa Dalil}

Sebagaimana di depan telah disebut bahwa Al Qur-an dan Hadits sebagai landasan ajaran Islam, lantas bagaimana tiga ayat Al Qur-an di atas yang telah dijadikan hujjah, dalil yang kokoh tentang ajaran Nur Muhammad. Jika di dalam 
surah Al Maidah ayat 15, ada lafal nur yang dimaksudkan Nabi Muhammad, apakah serta merta itu sebagai hujjah tentang Nur Muhammad ? Apakah Muhammad saw. sebagai nur atau cahaya karena membawa ajaran yang terang bukan gelap yaitu Islam itu sama dengan Nur Muhammad sebagai suatu konsep asal muasal segala yang maujud ? Karena tafsir-tafsir dari ayat tersebut tidak dijumpai satupun ayat dari situlah Nabi menjelaskan atau ulama salaf menerangkan sebagai hujjah ajaran Nur Muhammad. Kecuali ayat itu karena nur yang dimaksudkan adalah Nabi Muhammad saw. lantas dikaitkan sebagai tafsirnya adalah Nur Muhammad.

Pemaknaan yang benar nur yang dimaksudkan adalah Nabi Muhammad saw. dan kitab yang dimaksudkan Al Qur-an. Penempatan kata nur di dalam ayat itu sejalan dengan peran beliau mengungkap apa yang disembunyikan Al Kitab, sedang yang gelap hanya terungkap oleh cahaya, demikian dijelaskan oleh Quraish Shihab. Lebih lanjut dia mengatakan, Nabi Muhammad saw. adalah cahaya, atau wujudnya adalah cahaya, atau yang diciptakan pertama kali adalah Nur(cahaya) Nabi Muhammad saw., maka itu hanya sangkaan orang-orang sufi. Dalam ayat yang lain surah Al Ahzab ayat 46, siraajan muniiraa, pelita yang terang benderang itu adalah Nabi Muhammad saw. Oleh orang-orang sufi siraajan muniiraa itu juga cahaya Muhammad, ini tentunya mengada-ada saja.

Sedangkan surah An Nur ayat 35, tidak dapat dipisahkan dengan ayat sebelumnya, yaitu ayat 34, Allah swt. menurunkan ayat-ayatNya menjelaskan segala tuntunan berbagai kebutuhan hidup manusia dalam dunia dan akhiratnya. Ayat-ayat itu berfungsi, Allah swt. pemberi cahaya kepada langit dan bumi, cahaya yang bersifat material dapat di inderawi maupun cahaya immaterial berupa cahaya kebenaran, keimanan, pengetahuan dan lain-lain.

Quraish Shihab menyatakan, nur artinya sesuatu yang menjelaskan atau menghilangkan kegelapan, sesuatu yang sifatnya gelap atau tidak jelas dan adanya dapat diketahui dengan adanya cahaya. Secara majazi pancaindera dinamai dengan nur, akal dapat menangkap dan menganalisa hal-hal yang abstrakpun juga disebut nur, ilmu yang menjelaskan juga disebut nur. Sehingga dengan demikian Allah swt. 
tidak mungkin dinamai Nur. Islam menolak penamaan yang demikian karena tidak ada sesuatupun yang serupa denganNya, laisa kamitslihi syai'un, Asy Syura 11.

Jadi mengkaitkan kata nur dalam Al Qur-an sebagaimana ayat-ayat di atas dengan Nur Muhammad sebagai sangkaan belaka yang tidak berdasar ilmu. Hadits yang diriwayatkan Abdurrazaq bin Hammam Ash Shan'ani tidak menyebutkan sanadnya sampai Jabir bin Abdullah da kitab yang di dalamnya tertulis hadits tersebut adalah kitab fiktif, suatu kitab yang tidak ada realitanya. Dan bila Imam As Suyuthi mengatakan hadits tersebut ghairu tsabit, hal itu dibantah oleh seorang ahli sufi Abdullah bin ash Shidiq al Ghumari, "Penilaian As Suyuthi atas hadits ini (ghairu tsabit) adalah sikap menggampangkan yang jelek, bahkan hadits ini tampak jelas kepalsuannya, jelas kemungkarannya, dan padanya terdapat nafas sufisme.”

Lebih lanjut dia mengatakan,"Allah Maha Mengetahui bahwa (hadits) ini semuanya tidak jelas asal-usulnya, Jabir radliyallahu 'anhu berlepas diri dari periwayatan hadits ini, demikian pula Abdurrazaq, ia idak pernah mendengarnya. Orang pertama yang memahurkan hadits ii adalah Ibnu Arabi al Hatim i. Maka sayapun (ghumari) tidak mengetahui dari siapa dia menerimanya meskipun ia seorang yang dapat dipercaya, oleh sebab itu pasti ada seoarang tasawuf zahid yang memaalsukannya." Al Ghumari mencontohkan hadits lain sdemisal Raasul bersabda,"Aku dulu adalah cahaya dihadapan Rabbku sebelum Dia menciptakan Adam selama 14.000 tahun. Dan seandainya bukan karena engkau (Muhammad), Aku tidak akan menciptakan alam semesta ini,"

Hadits ini juga tidak ada asal-usulnya dan kitab-kitab maulid Nabi banyak dijumpai hadits palsu semacam ini. Dan sebagaimana disebut di atas tentang cerita penciptaan yang berasal dari Nur Muhammad dari sejak Nabi Adam as. sampai Nabi Muhammad saw.terlihat nama-nama orang yang direkam secara sembarangan. Apakah berita nama-nama yang tercantum dalam urutan atau nasab itu mempunyai kwalitas falid atau shahih? Atau pembuat cerita asal menyebut saja suatu nama lantas ditulis? Lafal Nur Muhammad itu tentu dalam kapasitas suci, mengapa darinya muncul atau terjadi sesuatu yang bertentangan dengan kesucian? 


\section{Kesimpulan}

Dari pembahasan tentang Nur Muhammad dari sisi kwalitas dalil baik Al Qur-an dan Hadits menunjukkan bahwa :

Hujjah mereka yang diambil dari Al Qur-an pemahamannya tentang Nur Muhammad sebagai awal setiap kejadian dan seterusnya terlihat terlalu dipaksakan padahal tidak ada satupun lafal nur dalam Al Qur-an yang relevan bila dikaitkan dengan konsep Nur Muhammad kecuali bila dihubungkan dengan diutusnya Muhammad saw.

Hadits yang menjadi dalil Nur Muhammad menurut ahli hadits dan sedikit ahli tasawuf yang memandangnya dari sudut tataran hadits kwalitasnya maudlu artinya palsu sebagaimana disepakati ahli ilmu bahwa hadits maudlu tidak dapat dijadikan dasar amaliah ibadah apalagi sebagai landasan aqidah. Upaya menyusun hadits maudlu apalagi untuk dijadikan dalil dalam hal aqidah resikonya sangat besar sebagaimana ditegaskan oleh Rasulullah saw, siapa yang berdusta atas nama Rasulullah Muhammad saw.dalam urusan agama ini dia berhak duduk di dalam neraka.

Sebagian besar penganut thariqat tasawuf walau tidak menjadikan Ibnu Arabi dan Al Hallaj sebagai tokoh wihdatul wujud menjadi panutan dalam berthariqat adalah memahami ajaran Nur Muhammad sebagai aqidah yang benar. Fahamnya Ibnu Arabi yaitu wihdatul wujud mempengaruhi hampir semua penganut thariqat tasawuf di seluruh dunia, seiring hal itu mereka hobi membuat hadits dan cerita palsu disekitar ajaran Nur Muhammad. Padahal menyandarkan ucapan kepada Nabi Muhammad saw. secara dusta konskwensinya neraka.

Pengakuan benar terhadap konsep Nur Muhammad melahirkan ajaran tentang wihdatul wujud, ajaran ini lahir dari sebagian kelompok sufi yang semula dibidani oleh Ibnu Arabi bahwa semua yang ada hakekatnya adalah Allah, ini termasuk dalam tasawuf sesat. 


\section{Daftar Pustaka}

Departemen Agama Republik Indonesia (1989), Al Qur-an dan Terjemahnya, Mahkota, Surabaya

M.Quraish Shihab (2006), Tafsir Al Mishbah, Lentera Hati, Cet.VI, Jakarta

Mubarak bin Mahfudh Bamualim (2007), Fadhilah Shalawat Kepada Nabi SAW. menurut Al Qur-an dan As Sunnah, Pustaka Imam Syafi'i, Jakarta

Nur Fauzan Ahmad (2010), Paham Nur Muhammad dalam Hikayat Nur Muhammad, Keterkaitannya dengan Teks Umdatul Anshab, Jurusan Sastra Indonesia, Fakultas Ilmu Budaya, Universitas Diponegoro, Semarang 